\title{
IdeAs
}

Idées d'Amériques

$6 \mid 2015$

Migrer dans les Amériques

\section{The portrayal of refugees in Canadian newspapers: The impact of the arrival of Tamil refugees by sea in 2010}

Portrait de réfugiés dans les journaux canadiens : l'impact de l'arrivée des réfugiés Tamil après leur traversée en 2010

O retrato de refugiados em jornais canadenses: o impacto da chegada de barco de refugiados do Tâmil

\section{Stelian Medianu, Alina Sutter et Victoria Esses}

\section{OpenEdition}

Journals

Édition électronique

URL : https://journals.openedition.org/ideas/1199

DOI : 10.4000/ideas.1199

ISSN : 1950-5701

Éditeur

Institut des Amériques

Référence électronique

Stelian Medianu, Alina Sutter et Victoria Esses, «The portrayal of refugees in Canadian newspapers:

The impact of the arrival of Tamil refugees by sea in $2010 »$, IdeAs [En ligne], 6 | 2015, mis en ligne le 16 décembre 2015, consulté le 20 octobre 2022. URL : http://journals.openedition.org/ideas/1199

DOI : https://doi.org/10.4000/ideas. 1199

Ce document a été généré automatiquement le 20 octobre 2022

\section{(c) (i) (9)}

Creative Commons - Attribution - Pas d'Utilisation Commerciale - Pas de Modification 4.0 International - CC BY-NC-ND 4.0

https://creativecommons.org/licenses/by-nc-nd/4.0/ 


\title{
The portrayal of refugees in Canadian newspapers: The impact of the arrival of Tamil refugees by sea in 2010
}

\author{
Portrait de réfugiés dans les journaux canadiens : l'impact de l'arrivée des \\ réfugiés Tamil après leur traversée en 2010 \\ O retrato de refugiados em jornais canadenses: o impacto da chegada de barco \\ de refugiados do Tâmil
}

Stelian Medianu, Alina Sutter et Victoria Esses

\section{Introduction}

1 On August 22, 2015, approximately 2,000 refugees fleeing from wars in Syria, Afghanistan and Iraq collided with Macedonian police as they crossed the GreekMacedonian border (The Associated Press, 2015). Just a few days earlier, Macedonia had declared a state of emergency and sealed its borders in response to the large influx of refugees in the previous months. In the two months before this event, an estimated 45,000 refugees crossed the Greek-Macedonian border. Unfortunately, this is just one of many examples of the scale of refugee movements that the world is witnessing today. According to an Australian research center, about 73 million people have been forced to leave their homes due to violence, conflict and other crises in the last four years (Alexander C., 2015). This corresponds to $1 \%$ of the world's population and is, according to the 2015 Global Peace Index, the highest proportion of displaced people since the Second World War (Whitman E., 2015).

2 The current research focuses on the media's portrayal of refugees, and in particular, the negative associations that are at times promoted. These negative associations can have dire consequences, affecting beliefs, emotions, and the treatment of refugees. 
Research has shown that humans have an implicit tendency to fear members of other groups and to more readily associate them with aversive emotions and stereotypes (Olsson A., Ebert J. P., Banaji M. R., and Phelps E. A., 2005). Once negative associations are learned, they can become automatically activated in individuals when they encounter members of the "other" group. Therefore, the repeated association of refugees with negative images and news stories can affect our perceptions of them at a fundamental level (Oliver M. B., Ramasubramanian S., and Kim J., 2007).

Previous research on media depictions of refugees has shown that these depictions are often negative and can problematize issues related to refugees. For example, Joshua Greenberg (2000) analyzed opinion discourses in five Canadian newspapers regarding the arrival of four Chinese refugee ships to Canada in 1999. Joshua Greenberg (2000) found that specific words were used to describe the migrants (e.g., "greedy", "selfish" or "illegal") and their arrival (e.g., "invasion" or "flood"). Moreover, Joshua Greenberg (2000) suggested that the use of these words helped create the impression that the immigration and refugee system in Canada was in crisis. Minelle Mahtani and Alison Mountz (2002) also investigated the arrival of the Chinese refugee ships to Canada in 1999, but instead of investigating how opinion discourses portrayed the event, they investigated how Canadian newspaper articles portrayed the event. The researchers found that the arrival of the Chinese refugee ships was framed as a crisis despite the relatively small number of refugees arriving by sea compared to the total number of refugees accepted to Canada every year. Furthermore, the researchers proposed that the media portrayal of the refugees' arrival aimed to create panic and anxiety among the public by describing them as bogus, as carriers of threatening diseases, and as potential terrorists.

4 Frances Henry and Carol Tator (2002) examined the media discourse of Canadian immigration in the National Post, a Canadian national newspaper known for its antiimmigrant bias. The results demonstrated that between 1998 and 2000 "the overwhelmingly majority of the articles, features, and editorials were opposed to current immigration policies and practices and critical of the values and norms of immigrants and refugees" (Henry F. and Tator C., 2002: 111). Furthermore, the researchers found several recurring themes. For example, refugees were described as bogus, and refugee policy was described as being lax and allowing terrorists to enter Canada. Negative media portrayals of refugees, however, are not unique to the Canadian context. For example, Natascha Klocker and Kevin Dunn (2003) analyzed media representations of refugees in Australia between August 2001 and January 2002 and found that both federal government media releases and newspaper articles used to a very large extent negative descriptive terms for asylum-seekers such as "illegitimate", "threatening" or "illegal".

5 Sean Hier and Joshua Greenberg (2002: 139) have suggested that negative media depictions often reflect the problematization of refugees as a response to uncertainties about citizenship and national identity "stemming from globalization and ideological realignments associated with the rise of neoliberalism". Uncertainty may also be based on a lack of clarity as to the host nation's level of obligation to provide protection for those seeking asylum, the types of assistance that should be provided to them, and whether refugees present a threat to members of host nations (Esses V. M., Medianu S., and Lawson S., 2013). According to Sean Hier and Joshua Greenberg (2002), when the media manufacture a crisis around the arrival of refugees, a problem is identified that 
can be readily solved, which, in turn, helps to reduce feelings of anxiety. Moreover, research suggests that uncertainty regarding the unexpected arrivals of refugees is especially likely to be viewed as a threat among individuals who think that there are not sufficient resources to deal with it (see Blascovich J. and Tomaka J., 1996). These perceived menaces, either tangible threats to the physical and economic well-being of the host society's members, or cultural threats to society, may in turn promote a variety of negative reactions (e.g., Esses V. M., Hodson G., and Dovidio J. F., 2003). The media may then reinforce these perceptions, providing one-sided negative portrayals of refugees that serve to further reduce uncertainty.

6 In the current study, we chose to investigate the media coverage of the arrival of a ship carrying Tamil refugees to the west coast of Canada (British Columbia) in August of 2010. This event is similar to several previous refugee ship arrivals to Canada, not only in the way the event was covered in the media and portrayed as a crisis, but also in its use to justify substantial changes to Canadian refugee policy.

7 Refugee arrivals by sea occur approximately once every decade in Canada (Bradimore A. and Bauder H., 2011). For example, in October 2009, seventy-six Tamil refugees arrived on the west coast of Canada, while in 2010, 497 Tamil refugees reached the same shores. These events were preceded by the 1999 arrival of 599 refugees from the Fujian province of China. Before that, in 1987, 174 Sikh refugees arrived on the east coast of Canada, while in 1986, 152 Sri Lankan refugees reached the same shores. These refugee numbers are small in comparison to the number of refugees that Canada accepts every year (Bradimore A. and Bauder H., 2011). In 2008, 36,000 people filed refugee claims within Canada or at a Canadian port of entry and about half of them received a positive response to their application for refugee status (Maytree, 2009).

Despite this reality, with the arrival of each refugee ship, the media tends to create a feeling of panic and anxiety among the public regarding the vulnerability of the Canadian immigration system, and this eventually prompts government officials to review refugee policy. For example, the Canadian media was extremely concerned with the arrival of ships carrying Tamil refugees in 1986 and Sikh refugees in 1987 to Canada. Only two years later, Bill C-55 was officially introduced creating the Immigration and Refugee Board with the goal of reducing bogus refugee claimants (Bradimore A. and Bauder H., 2011). In 1999, the arrival of migrants from the Fujian province of China was met with similar scepticism by the Canadian media. Not long after that, in 2002, the Immigration and Refugee Protection Act was introduced (Bradimore A. and Bauder H., 2011). Finally, and of specific relevance to the current research, on August 13, 2010, the MV Sun Sea arrived on the shores of British Columbia carrying 497 Tamil refugees. Immediately after that, on October 21, 2010, the federal government introduced Bill C-49: Preventing Human Smugglers from Abusing Canada's Immigration System Act in Parliament (Bradimore A. and Bauder H., 2011).

The context behind the arrival of the Tamil refugees in British Columbia in 2010 is important. The 492 Tamil refugees aboard the MV Sun Sea vessel fled Sri Lanka to escape the bloody aftermath of a civil war that had been going on for twenty years. Although the Sri Lankan civil war officially ended in May 2009, Tamils still faced the threat of violence. As a result, many Tamils had to flee for safety (Human Rights Watch, 2010). Indeed, human rights agencies expressed extreme concern over human rights violations in Sri Lanka. Concerned citizens, many of them of Tamil origin, also protested in the streets of Toronto, Canada and condemned the ongoing violence in Sri 
Lanka. Despite this reality, the 492 Tamil refugees arriving by ship received a cold welcome from the Canadian media and public (Bradimore A. and Bauder H., 2011).

According to a public opinion poll (Angus Reid, 2010), more than half of Canadians (64\%) were following the story of the arrival of the Tamil refugees in the media "very closely" or "moderately closely", including $72 \%$ of respondents in British Columbia. The poll also showed that $63 \%$ of Canadians thought the ship carrying the Tamil refugees should have been sent back and not allowed to reach Canadian shores. $83 \%$ of Canadians also thought that the Tamil refugees were bogus and were trying to jump the immigration queue. Even under the assumption that the refugee claims were legitimate and that there were no links between the Tamil refugees and any terrorist organization, $48 \%$ of the respondents still believed that the passengers and the crew should be deported to their country of origin. Only $35 \%$ of the respondents said that the Tamil refugees should be allowed to stay in Canada and granted official refugee status. By examining how the media depicted refugees and this incident at this time, we may gain insight into potential media effects on these attitudes.

Two main questions were addressed in our research study. First, we investigated how refugees are generally portrayed in Anglophone newspapers in Canada. Based on previous research (e.g., Esses V. M., Veenvliet S., Hodson G., and Mihic L., 2008; Greenberg J., 2000), we expected that refugees would be portrayed in a negative light, described as immoral and likely to cheat the system to claim refugee status. Second, we were interested in how a unique event - in this case, the arrival of the Tamil refugee ship to Canada in 2010 - impacted the depiction of refugees. In order to investigate this question, we examined how refugees were portrayed in Anglophone newspapers in Canada six months before and six months after the arrival of the Tamil refugees.

\section{Method}

\section{Newspaper Articles}

The newspapers were selected according to their circulation and location. We selected the most highly circulated newspapers in Canada - Toronto Star and The Globe and Mail as well as the newspapers Vancouver Sun, Calgary Herald, National Post and Ottawa Citizen to cover the major cities in Canada. The period under investigation included six months before and six months after the arrival of the Tamil refugee ship to Victoria, Canada, on the $13^{\text {th }}$ of August 2010 . To identify all the relevant newspaper articles, we used the ProQuest Canadian Newsstand database, an extensive online database for Canadian newspapers. Similar to Daniela Dimitrova and Jesper Stromback's (2005) procedure, we searched for all articles and editorials that included the key term "refugee" in the headline or abstract and were longer than 400 words. The search yielded a total of 95 articles for the period ( 46 articles six months before and 49 articles six months after the arrival of the Tamil refugee ship): Toronto Star $(n=36)$, Vancouver Sun $(n=17)$, National Post $(n=17)$, Ottawa Citizen $(n=11)$, Calgary Herald $(n=9)$ and The Globe and Mail $(n=5)$. One article published on the $13^{\text {th }}$ of August 2010 was included in the six months before the event period. There was no multiple coverage of the same article or editorial in the selected newspapers. 


\section{Coding Scheme}

13 The coding scheme consisted of four categories based on those of David Snow and Robert Benford (1988) and Conny Roggeband and Rens Vliegenthart (2007). The first category, voice/standing, refers to the source of the information and the use of specific quotes, statistics or alternatives provided in the articles. The second category, diagnosis, is concerned with the problem, causes and/or the entity being perceived to be responsible for causing the problem. The third category, prognosis, looks at the potential solutions to the problem. Finally, the fourth category, call for action, asks whether specific actions are suggested or not, who is acted on, what the boundaries of these actions are, and/or how non-action is legitimized.

\section{Coding Procedure}

14 Two research assistants who were uninvolved in the selection of the articles independently coded the articles based on the questions within the four categories mentioned above. Each research assistant was randomly assigned to half of the articles for the time period six months before the arrival of the Tamil refugee ship and six months after the arrival of the Tamil refugee ship. After coding all articles, we asked each research assistant what the common themes were based on their answers to the coding scheme. Then, we compared and discussed the results of each coder in order to decide on the final themes. Importantly, the final themes had to fulfil two criteria. First, each theme should not be too narrow to maintain relevance. Second, we aimed for a minimum overlap between themes in order to ensure their distinctiveness. After determining the final themes, the two research assistants assigned each article to the corresponding theme. Each article could be assigned to only one theme. The inter-rater reliability for assigning the articles to the specific themes was good (IR $=.80$; Holsti O., 1969).

\section{Results}

\section{Themes}

The analyses showed that the newspapers depicted refugees in terms of four themes: victim, bogus, criminal/terrorist, and legal debate. Articles with the victim theme tended to focus on the hardships that refugees endured in their home countries and often also in their host countries, by reporting individual stories of refugees. For example, on December 23, 2010, the Vancouver Sun reported the story of a Tamil woman who was on board the Tamil refugee ship in question. The article described the dire circumstances that led the woman to flee with her children, the tough circumstances on the vessel, and their shocking arrival to Canada where they were held in custody for three months. Furthermore, many of the victim articles pointed out the need for Canada to continue accepting refugees. In contrast, the articles using the bogus theme focused on how refugee claimants are often illegitimately seeking refuge in Canada, and described the Canadian immigration system, for example, as "sluggish" or "broken", in need of being "fixed" (Brennan R., 2010; National Post, 2010). In fact, many of these articles suggested that refugees are taking advantage of the Canadian 
immigration system and that the Canadian immigration system should be tightened. The articles using the criminal/terrorist theme described refugees as having entered Canada with the help of human smugglers or associated them with terrorism. For example, on November 22, 2010, the National Post wrote "militants from war-torn Somalia are using refugee routes into Yemen as a cover for making contact with an alQaeda group responsible for a series of plots against the West" (Spencer R., 2010). Finally, the articles using the legal debate theme discussed possible solutions to current problems within the Canadian Immigration and Refugee Protection Act. $40 \%$ of the total number of articles analysed corresponded to the victim theme, $29.5 \%$ to the bogus theme, $20 \%$ to the criminal/terrorist theme, and $10.5 \%$ to the legal debate theme.

\section{Change in Predominance of Themes in Response to the Arrival of the Tamil Refugees}

When looking at the themes of the articles during the six months before the arrival of the Tamil refugees, the most common theme was the bogus theme (45.7\%) followed by the victim (30.4\%), legal debate (15.2\%) and criminal/terrorist theme (8.7\%; see also table 1). In comparison to the six months before the arrival of the Tamil refugee ship, a larger percentage of the total number of newspaper articles contained the victim theme in the six months period after their arrival (an increase from $30.4 \%$ to $49 \%$; see table 1). At the same time, the criminal/terrorist theme increased from $8.7 \%$ to $30.6 \%$, whereas the bogus theme ( $45.7 \%$ to $14.3 \%$ ) and the legal debate theme ( $15.2 \%$ to $6.1 \%$ ) decreased (see table 1). To test whether these differences between before and after the event were statistically significant, we conducted chi-square tests. The results showed that there was a significant association between newspaper theme and time period, $X^{2}(3)=17.52, p<.01$. The decrease in articles with the bogus theme after the event was significant (from 21 to $7, p<.05$ ) and the increase in articles with the criminal/terrorist theme after the event was marginally significant (from 4 to $15, p<.10$ ). The effects for the victim and legal debate themes were not significant.

These changes might be better understood when looking at the three spikes in number of articles published throughout the period investigated (see figure 1). The first spike was in March 2010, before the arrival of the Tamil refugee ship. The majority of these articles portrayed refugees as bogus and were related to the discussion of Bill C-11 "The Balanced Refugee Reform Act". The bill aimed to speed up the decision-making process of deciding refugee status, to designate certain "safe" countries of origin, and to expedite removals of failed claimants. It became law in June 2010. Furthermore, as expected, most articles were published in the second half of August 2010 - the second spike, when the Tamil refugee ship had arrived in Canada. During this time, refugees, in particular Tamil refugees, were either portrayed as victims or criminals/terrorists. In fact, the majority of articles portraying refugees in criminal/terrorist terms were published during the three months after the arrival of the Tamil refugee ship. In line with these results, another third spike in number of articles published was in October 2010, when the Canadian Government discussed a bill to prevent human smugglers from abusing Canada's immigration system (Bill C-49). 
Refugee frames used by the media six months before and after the arrival of a boat carrying Tamil refugees to Canada

\begin{tabular}{lcc}
\hline & 6 months before & 6 months after \\
\hline Victim & $30.4 \%$ & $49.0 \%$ \\
Criminal Terrorist & $8.7 \%$ & $30.6 \%$ \\
Bogus & $45.7 \%$ & $14.3 \%$ \\
Legal Debate & $15.2 \%$ & $6.1 \%$ \\
Total & $100 \%$ & $100 \%$ \\
\hline
\end{tabular}

ESSES, MEDIANU AND SUTTER

Number of articles referring to refugees between February 2010 and 2011

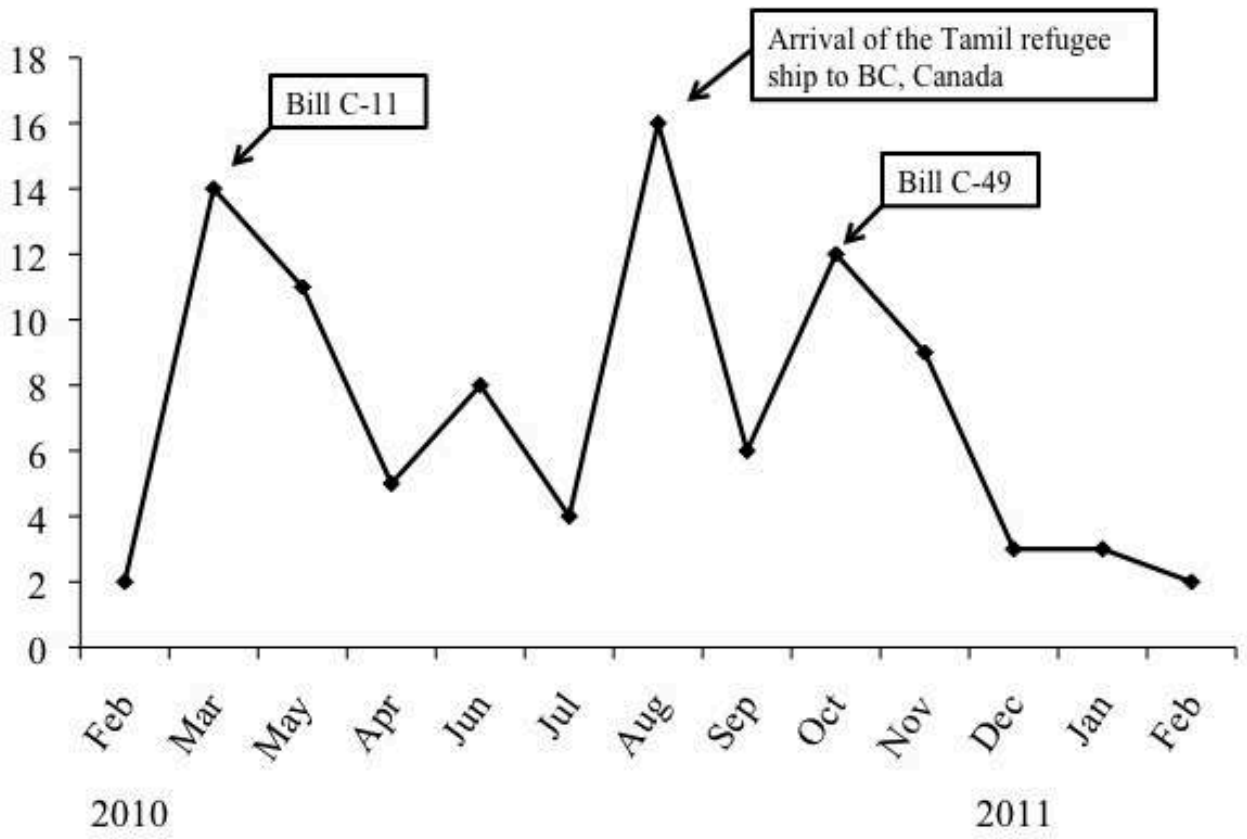

ESSES, MEDIANU AND SUTTER

\section{Differences Between the Newspapers}

There was also considerable variation between newspapers. In terms of amount of newspaper coverage of refugees, the Toronto Star had the highest share. Indeed, the Toronto Star, one of the most highly circulated newspapers in Canada, published $39 \%$ of the total number of articles before the arrival of the Tamil refugee ship and 37\% after the arrival. Interestingly, The Globe and Mail, the second largest newspaper in terms of circulation in Canada, had the lowest share of newspaper coverage before (7\%) and after (4\%) the arrival of the Tamil refugees, followed by the Calgary Herald with a share of $9 \%$ before and $10 \%$ after the arrival of the Tamil refugee ship. Both the Vancouver Sun and the Ottawa Citizen increased their shares after the arrival of the Tamil refugee ship, from $15 \%$ to $20 \%$, and from $7 \%$ to $16 \%$, respectively. Finally, the National Post reduced its share after the arrival of the Tamil refugees from $24 \%$ to $12 \%$ (see figure 2). This is interesting because it shows that Canadian newspapers differ markedly in the relative importance they place on publishing articles about refugee issues. 


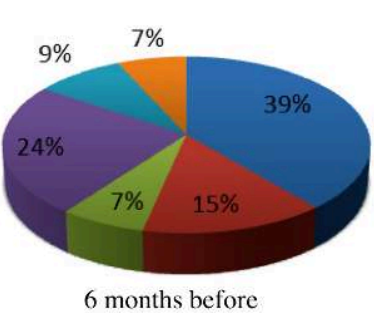

ESSES, MEDIANU AND SUTTER

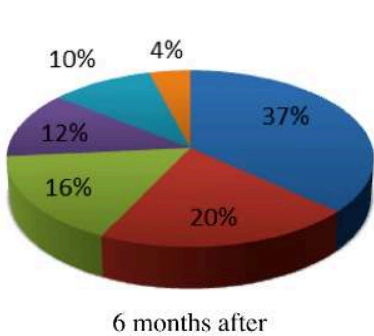

- The Toronto Star

- The Vancouver Sun

- The Ottawa Citizen

National Post

- Calgary Herald

The Globe and Mail

The Toronto Star and Vancouver Sun were more likely to frame refugees as victims after than before the arrival of the Tamil refugee ship. From all the articles published in the Toronto Star, 33.3\% of the articles framed refugees as victims before the arrival of the Tamil refugee ship and 55.6\% after the arrival. Similarly, from all the articles published in the Vancouver Sun, $42.9 \%$ of the articles framed refugees as victims before the arrival of the Tamil refugee ship and $80 \%$ after the arrival. In contrast, from all the articles published in the National Post, a more conservative newspaper, $36.4 \%$ of the articles framed refugees as bogus before the arrival of the Tamil refugee ship and $50 \%$ of the articles framed refugees as criminals/terrorists after the arrival of the Tamil refugee ship. This is interesting because it suggests that the political orientation of a newspaper has a considerable impact on how issues surrounding refugees, such as the arrival of the Tamil refugee ship to Canada, are portrayed in the newspaper's articles. Moreover, the different portrayals of refugees provide the general public with markedly different interpretations of the same event.

\section{Discussion}

The aim of this study was to investigate how refugees are generally portrayed in Anglophone newspapers in Canada and how the arrival of the Tamil refugee ship to Canada in 2010 impacted their depiction. This is important because the portrayal of refugees in the media can influence how the public perceives refugees (Oliver M. B. et al., 2007; Olsson A. et al., 2005). People's perception of refugees may in turn affect how these individuals are treated in society, including what kind of policies are implemented to handle their refugee claims and what type of assistance is provided to them.

21 The results revealed that the overall portrayal of refugees in the Canadian press was mixed. As expected, many Anglophone Canadian newspapers portrayed refugees in a negative light, either as bogus or criminals/terrorists. Interestingly, the arrival of the Tamil refugee ship seemed to have an impact on these depictions. Whereas before the event refugees were more likely to be portrayed as bogus, they were more likely to be portrayed as criminals/terrorists after the event, being blamed for entering Canada with the help of human smugglers or even being suspected of terrorist links. However, unexpectedly, refugees were not only portrayed in negative terms. Canadian newspapers also depicted refugees as victims in need of help. This was particularly the 
case in two newspapers - the Toronto Star and Vancouver Sun. Finally, only a small number of the newspaper articles discussed legal issues about refugees.

It is interesting to note that there were substantial variations in the extent to which the newspapers reported on the issue of the refugee arrivals, as well as in their portrayals of refugees. These variations are likely due to the different target audiences of the newspapers and their agenda setting. Newspapers often speak to distinct audiences and by doing so endorse either a more liberal or conservative political orientation in their news reporting. For example, the National Post, a more conservative newspaper, was more likely to use the bogus or criminal/terrorist theme when reporting on issues related to refugees. In addition, the geographical location might have had an impact on the news coverage, especially on the West Coast of Canada where the Tamil refugee ship arrived. For example, the Vancouver Sun, located close to where the Tamil refugees arrived, reported on refugee issues to a larger extent after the arrival of the Tamil refugee ship, portraying them mainly as victims. This may have been due to several factors such as the liberal political orientation of the newspaper, the desire to inform the public on a very local issue, and the large proportion of immigrants making up the population of the city of Vancouver.

The arrival of the Tamil refugee ship to Canada in August 2010 not only affected how the media portrayed refugees, but also how the Canadian government proposed to handle refugee claimants. In particular, in October 2010, Bill C-49, labelled "Preventing Human Smugglers from Abusing Canada's Immigration System Act", was first introduced in Canadian Parliament (Canadian Council for Refugees, 2015a). The bill was heavily criticized for seeming to blame, and focusing on how to treat, refugees arriving in a similar manner, rather than focusing on the human smugglers who bring them in. The bill was also criticized for violating the Canadian Charter of Rights and Freedoms as well as Canada's international human rights obligations (Canadian Council for Refugees, 2015a; Ontario Council of Agencies Serving Immigrants, 2010). While the bill was not passed, the provisions it contained were reintroduced and became law with only a few modifications in 2012 (Canadian Council for Refugees, 2015a). More recently, in January 2015, the Conservative government announced that Canada would accept 10,000 Syrian refugees over a period of three years and promised, if re-elected in October 2015, to increase this number with an additional 10,000 refugees over the next four years. This number pales in comparison to the realistic needs of refugees around the world. Thus, it is not surprising that, today, Canada's reputation as a welcoming country to refugees has considerably eroded.

However, Canada has not always been so unwelcoming to refugees. In fact, in 1986, the UNHCR awarded Canada the Nansen Medal for its outstanding work on behalf of the forcibly displaced (UNHCR, 2015). Indeed, in the past, Canada has accepted refugees from all over the world (Canadian Council for Refugees, 2015b). For example, in 1956, Canada welcomed 37,000 Hungarian refugees fleeing the violent Soviet repression of the Hungarian revolution. In 1968, Canada took in 10,975 Czechoslovakian refugees following the Prague Spring. In June 1979 the Canadian government announced that it would resettle 50,000 South-East Asians by the end of 1980. In fact, for the years 1978-1981, refugees made up 25\% of all immigrants to Canada. In recent years, that percentage has dropped to less than $10 \%$. Welcoming refugees to a country starts with how they are depicted in the media. 
In theory, effective journalism should report issues as they occur and provide an unbiased account of social issues so that people are enabled to form their own opinions and to make informed decisions (Herrman E. S. and Chomsky N., 1988). However, many times media frames or filters are used to form, misrepresent or even censor journalism (Herman E. S. and Chomsky N., 1988). By repeatedly referring to refugees as bogus, criminals and terrorists, the media can have a lasting effect on how members of the public perceive refugees. The media can also potentially affect how refugees are treated in society and how people respond to current and future immigration legislation concerning refugees. If people perceive refugees as immoral, they may be more likely to perceive refugees as less than human and thus not worthy of humane treatment (see Opotow S., 1995). That is, if refugees are perceived as not sharing our humanity, the fate of a refugee is less relevant to our own and their interests may be ignored (Schwartz S. H. and Struch N., 1989). In contrast, if the plight of refugees as victims is more fully conveyed, governments may be more willing to "open official channels to migrants" (BBC, 2015), instead of closing borders and building fences to prevent access and much needed help to the millions of refugees present in the world today.

\section{BIBLIOGRAPHIE}

Alexander, Caroline, “World hasn't had so many refugees since 1945, report says”, Bloomberg Business, June $17^{\text {th }}$ 2015. Available online: http://www.bloomberg.com/news/articles/2015-06-17/ world-hasn-t-had-so-many-refugees-since-1945-report-says. Page consulted on August $23^{\text {rd }} 2015$.

Angus Reid Public Opinion, “Almost half of Canadians believe Tamil migrants should be deported”, 2010. Available online: http://angusreidglobal.com/wp-content/uploads/

2010/08/2010.08.19_Migrants_CAN.pdf. Page consulted on October $20^{\text {th }} 2012$.

British Broadcasting Corporation (BBC), "Europe "must open official channels for migrants", August $25^{\text {th }}$ 2015. Available online: http://www.bbc.com/news/world-europe-34049512. Page consulted on August $28^{\text {th }} 2015$.

Blascovich, Jim, and Tomaka, Joe, “The biopsychosocial model of arousal regulation”, In Mark Zanna (Ed.), Advances in experimental social psychology, New York, Academic Press, Vol. 28, 1996, p. $1-51$.

Bradimore, Ashley, and Bauder, Harald, "Mystery ships and risky boat people: Tamil refugee migration in the newsprint media", Canadian Journal of Communication, vol. 36, $\mathrm{n}^{\circ} 4,2012$, $\mathrm{p}$. 637-661.

Brennan, Richard J., "False refugees face swift kick out door conservatives plan asylum overhaul, but critics cry foul over minister's move to define 'safe' countries", Toronto Star, March 31 ${ }^{\text {st }}, 2010$. Available online: http://search.proquest.com/docview/439651753?accountid=15115. Page consulted on August $23^{\text {rd }} 2015$.

Canadian Council for Refugees, “Sun Sea: five years later”, August 2015. Available online: http:// ccrweb.ca/sites/ccrweb.ca/files/sun-sea-five-years-later.pdf. Page consulted on August $28^{\text {th }}$, 2015a. 
Canadian Council for Refugees, "Brief history of Canada's responses to refugees". Available online: http://ccrweb.ca/sites/ccrweb.ca/files/static-files/canadarefugeeshistory4.htm. Page consulted on October $17^{\text {th }}, 2015 \mathrm{~b}$.

Dimitrova, Daniela V., and Strömbäck, Jesper, "Mission accomplished? Framing of the Iraq War in the elite newspapers in Sweden and the United States", Gazette, vol. 67, n 5, 2005, p. 399-417.

Esses, Victoria M., Gordon Hodson, and John F. Dovidio. "Public attitudes toward immigrants and immigration: Determinants and policy implications”, In Charles M. Beach, Alan G. Green, and Jeffery G. Reitz (Eds.), Canadian immigration policy for the 21st century, Montreal, Canada, McGill Queen's Press, 2003, p. 507-535

Esses, Victoria M., Medianu, Stelian and Andrea, S., "Uncertainty, threat, and the role of the media in promoting the dehumanization of immigrants and refugees", Journal of Social Issues vol. $69, \mathrm{n}^{\circ} 3,2013$, p. 518-536.

Esses, Victoria, M., Veenvliet, Scott, Hodson, Gordon, and Mihic, Ljiljana, "Justice, morality, and the dehumanisation of refugees", Social Justice Research, vol. 21, 2008, p. 4-25.

Greenberg, Joshua, "Opinion discourse and Canadian newspapers: the case of the Chinese "boat people”", Canadian Journal of Communication, vol. 25, n 4, 2000, p. 517-537.

Henry, Frances, and Tator, Carol, Discourses of domination: Racial bias in the Canadian Englishlanguage press, Toronto, University of Toronto Press, 2002.

Herman, Edward S., and Chomsky, Noam, Manufacturing consent: the political economy of the mass media, New York, Pantheon, 1988.

Hier, Sean P., and Joshua L. Greenberg. "Constructing a discursive crisis: Risk, problematization and illegal Chinese in Canada", Ethnic and Racial Studies, vol. 25, n 3, 2002, p. 490-513.

Holsti, Ole R., Content analysis for the social sciences and humanities, Reading, MA, Addison-Wesley, 1969.

Human Rights Watch, “Sri Lanka: Country Summary”, 2010. Available online: https:// www.hrw.org/world-report/2010/country-chapters/sri-lanka. Page consulted on May $29^{\text {th }} 2014$.

Klocker, Natascha, and Kevin M. Dunn, "Who's driving the asylum debate: newspaper and government representations of asylum seekers", Media International Australia, vol. 109, 2003, p. 71-93.

Mahtani, Minelle, and Mountz, Alison, "Immigration to British Columbia: Media representations and public opinion", Metropolis Working Paper, 2002. Available online: http://mbc.metropolis.net/ assets/uploads/files/wp/2002/WP02-15.pdf. Page consulted on June $1^{\text {st }} 2012$.

Maytree, "Maytree: Policy in focus", September $9^{\text {th }}$ 2009. Available online: http://maytree.com/ PDF_Files/MaytreePolicyInFocusIssue9.pdf. Page consulted on May $29^{\text {th }} 2014$.

National Post, "Reforming the refugee system; we can hardly applaud Kenney's changes enough", National Post, March $31^{\text {st }}$ 2010. Available online: http://search.proquest.com/docview/330946270? accountid=15115. Page consulted on August $25^{\text {th }} 2015$.

Oliver, Mary Beth, Ramasubramanian, Srividya, and Kim, Jinhee, "Media and racism”, In David R. Roskos-Ewoldsen and Jennifer Monahan (Eds.), Communication and social cognition: Theories and methods, Mahwah, NJ, Erlbaum, 2007, p. 273-294.

Olsson, Andreas, Ebert, Jeffery P., Banaji, Mahzarin R., and Phelps, Elizabeth A., "The role of social groups in the persistence of learned fear", Science, vol. 309, nº 5735, 2005, p. 785-787. 
Ontario Council of Agencies Serving Immigrants, "Information on Bill C-49", October $31^{\text {st }} 2010$. Available online: http://www.ocasi.org/sites/default/files/2010,\%200CASI_BillC-49_information.pdf. Page consulted on August $28^{\text {th }} 2015$.

Opotow, Susan "Drawing the line: Social categorization, moral exclusion, and the scope of justice”, In Barbara Benedict Bunker, and Jeffery Z. Rubin (Eds.), Conflict, cooperation, and justice: Essays inspired by the work of Morton Deutsch, San Francisco, Jossey-Bass, 1995, p. 347-379.

Roggeband, Conny, and Vliegenthart, Rens, "Divergent framing: The public debate on migration in the Dutch parliament and media, 1995-2004", West European Politics, vol. 30, n 3, 2007, p. 524-548.

Schwartz, Shalom H., and Struch, Naomi, "Values, stereotypes, and intergroup antagonism", In Daniel Bar-Tal, Carl F. Grauman, Arie W. Kruglanski, and Wolfgang Stroebe (Eds.), Stereotypes and prejudice: Changing conceptions, New York, Springer-Verlag, 1989, p. 151-167.

Snow, David A. and Benford, Robert D., "Ideology, frame resonance, and movement participation", International Social Movement Research, vol. 1, 1988, p. 197-217.

Spencer, Richard, “Terrorists posing as refugees to Yemen; leaving Somalia", National Post, November 22th 2010. Available online: http://search.proquest.com/docview/809931830? accountid=15115. Page consulted on August $25^{\text {th }} 2015^{1}$.

The Associated Press, "Europe migrants: 2,000 rush past police into Macedonia", CBC News, August $22^{\text {nd }}$ 2015. Available online: http://www.cbc.ca/news/world/europe-migrants-2-000-rushpast-police-into-macedonia-1.3200282. Page consulted on August $23^{\text {rd }} 2015$.

United Nations High Commissioner for Refugees (UNHCR), "Archive of Past Nansen Winners". Available online: http://www.unhcr.org/pages/49c3646c467-page5.html. Page consulted on October $17^{\text {th }} 2015$

Whitman, Elizabeth, "Global refugees 2015: more people fleeing home than any other time since World War II", International Business Times, June 17 ${ }^{\text {th }} 2015$. Available online: http:// www.ibtimes.com/global-refugees-2015-more-people-fleeing-home-any-other-time-world-warii-1971066. Page consulted on August 25 2015.

\section{NOTES}

1. This is a newspaper article published in 2010 and can only be accessed through a database such as the ProQuest Canadian Newsstand database. Subscribers only have access to proquest links.

\section{RÉSUMÉS}

Les médias jouent un rôle essentiel dans la façon dont le public intègre et comprend les sujets à controverse telle que l'arrivée de réfugiés dans les pays occidentaux. Ils peuvent en effet contribuer de façon significative à façonner les réactions du public à ces questions en présentant des arguments encourageant telle ou telle interprétation du problème. Notre recherche s'attache à analyser la façon dont les réfugiés sont présentés avant et après l'arrivée controversée d'un 
bateau transportant vers le Canada des réfugiés Tamil, en août 2010. Nous avons mené cette étude à partir de l'analyse du contenu de 102 articles publiés dans six journaux canadiens, six mois avant et six mois après l'événement. Le choix des journaux a été déterminé par l'importance de leur diffusion et la diversité des points de vue politiques. Les analyses ont révélé des variations substantielles dans l'importance accordée à l'arrivée des réfugiés ainsi que dans les descriptions de ces derniers. Les journaux de centre-gauche traitaient davantage que les journaux conservateurs des questions relatives aux réfugiés et avaient davantage tendance à les présenter comme des victimes. Les analyses ont également démontré l'impact de l'arrivée du bateau transportant les réfugiés Tamil sur la description de ces derniers. Alors que, avant l'événement, les réfugiés étaient plutôt présentés comme ayant eu recours à de fausses déclarations pour obtenir le statut de réfugiés, après l'événement, ils étaient plutôt dépeints comme des délinquants ou des terroristes ou bien encore des victimes. Ces résultats ont des implications significatives sur la façon dont les réfugiés sont perçus et traités par la société, y compris sur les politiques mises en place pour gérer les demandes d'obtention du statut de réfugié et sur le type d'assistance apportée aux réfugiés.

News media make an essential contribution to the way in which the public processes and understands controversial issues such as the arrival of refugees in western countries. Indeed, they can have an important role in shaping the public's responses to these issues by framing arguments to encourage a particular interpretation of an issue. The current research investigates how refugees were portrayed before and after the controversial arrival of a ship carrying Tamil refugees to Canada in August 2010. The study was based on the content analysis of 102 articles published in six Canadian newspapers six months before and six months after the event. The newspapers were selected based on their large circulation and diverse political slants. The analyses revealed substantial variation in the extent to which the newspapers reported on the issue of refugee arrivals, as well as in their portrayals of refugees. Liberal newspapers were more likely than conservative newspapers to include reports on issues surrounding refugees and were more likely to portray refugees as victims. Also, the analyses demonstrated the impact of the arrival of the Tamil refugee ship on the portrayal of refugees. Whereas before the event refugees were portrayed more in terms of false claims for refugee status, after the event refugees were portrayed more in terms of being either criminals and terrorists or victims. These results have important implications for how refugees are perceived and treated in society, including what kind of policies are implemented to handle refugee claims and what type of assistance is provided to refugees.

A mídia presta uma contribuição essencial para a forma como o público processa e entende questões controversas, tais como a chegada de refugiados em países do Ocidente. Com efeito, a mídia pode ter um papel importante na maneira como o público reage a essas questões, por meio da formulação de argumentos que incentivam interpretações particulares sobre um determinado assunto. Esta pesquisa investiga a maneira com que refugiados foram retratados antes e depois da controversa chegada, ao Canadá, de um barco transportando refugiados do Tâmil, em agosto de 2010. Uma análise de conteúdo foi conduzida a partir de 102 artigos publicados em seis jornais canadenses, seis meses antes e seis meses depois do acontecimento. Os jornais foram selecionados com base em sua ampla circulação e em suas inclinações políticas variadas.

A análise revelou uma variação substancial na forma como os jornais noticiaram a questão da chegada de refugiados, assim como em seus respectivos retratos destes últimos. Jornais liberais foram mais propensos do que jornais conservadores a apresentar relatórios sobre questões envolvendo refugiados, e também mais propensos a retratá-los como vítimas. Além disso, a análise demonstrou o impacto da chegada do barco vindo do Tâmil no retrato de refugiados. Enquanto antes do acontecimento os refugiados eram retratados sobretudo a partir da atribuição, a eles, de falsas reivindicações para seu estatuto, após o acontecimento eles foram retratados 
mais como criminosos, terroristas ou vítimas. Esses resultados têm importantes implicações na maneira como os refugiados são percebidos e tratados pela sociedade, o que inclui o tipo de políticas implementadas para lidar com as suas reivindicações e o tipo de assistência prestada a eles.

\section{INDEX}

Keywords : refugee, media, media coverage, refugee crisis, content analysis

Palavras-chave : refugiado, mídia, cobertura da mídia, crise dos refugiados, análise de conteúdo Mots-clés : réfugié, médias, couverture médiatique, crise des réfugiés, analyse de contenu

\section{AUTEURS}

\section{STELIAN MEDIANU}

Stelian Medianu is currently a Postdoctoral Fellow at Western University, Canada. He has a doctoral degree in Social Psychology with a specialization in Migration and Ethnic Relations. His main area of research focuses on the effects of media on attitudes toward immigrants and refugees.smedian@uwo.ca

\section{ALINA SUTTER}

Alina Sutter is a Ph.D. Candidate in Social Psychology at Western University, Canada. Her research aims to better understand the relationships between national identity, perceived threat and prejudice towards immigrants and refugees as well as the antecedents and behavioural consequences of the dehumanization of refugees. asutter2@uwo.ca

\section{VICTORIA ESSES}

Victoria Esses (Ph.D. University of Toronto) is Professor of Psychology and Director of the Centre for Research on Migration and Ethnic Relations at the University of Western Ontario. She is Principal Investigator of the Pathways to Prosperity Partnership (www.p2pcanada.ca), a national alliance of university, community and government partners dedicated to fostering welcoming communities and promoting the integration of immigrants and minorities across Canada. Her research examines public attitudes toward immigration and cultural diversity, promising practices in settlement and integration, and factors promoting the settlement and integration of immigrants and refugees. In 2010 she was awarded the Harold Crabtree Foundation Award in Public Policy Research and the Faculty Scholar Award for her work in this area. vesses@uwo.ca 